\title{
Short-term international assignments. Military perspectives and implications for international human resource management
}

\author{
Marian Crowley-Henry*, Graham Heaslip \\ National University of Ireland Maynooth, Co Kildare, Ireland
}

\section{A R T I C L E I N F O}

\section{Article history:}

Received 16 May 2013

Accepted 15 February 2014

Available online 14 March 2014

Handling Editor: Sabina Siebert

\section{Keywords:}

Short-term international assignment

Military

Irish Defence Forces

International human resource management

IHRM

Expatriation cycle

Deployment cycle

\begin{abstract}
A B S T R A C T
Short-term international assignments have been under-explored in international human resource management (IHRM) literature and research. Equally, there is a dearth of studies on international mobility beyond multinational corporations. Drawing on an exploratory study of short-term international assignments in the Irish Defence Forces, this paper considers the implications for IHRM.
\end{abstract}

(c) 2014 Elsevier Ltd. All rights reserved.

\section{Introduction}

Short-term international assignments have received limited attention in international human resource management. As a category of international staffing alternatives (Collings, Scullion, \& Morley, 2007), the mention is typically a paragraph differentiating short-term international assignments from other international staffing options (e.g., Dickmann \& Baruch, 2011; Doherty \& Dickmann, 2008; Hayton, Biron, Christiansen, \& Kuvaas, 2012).

This paper examines what is currently known about short-term international assignments (STIAs) in international human resource management (IHRM). Drawing on an exploratory study of STIAs in the Irish military, it suggests a more detailed consideration of STIAs in IHRM is warranted. In certain organizations and for certain professions, STIAs are an integral component of the organizational career of employees. This is the case for those employed in military forces. Deployed personnel in the Irish Defence Forces embark on STIAs as an integral and routine facet of a military career. Since 1958, the Irish Defence Forces have had a continuous involvement in overseas peacekeeping missions, allied to the intention of the UN Security Council to "sub-contract" the military sections of mandates to regional organisations the deployment of Irish Defence Forces personnel overseas is set to continue.

The research objective of this paper is to initiate a re-examination of STIAs in IHRM. Firstly, in the literature review, we set out

\footnotetext{
* Corresponding author. Tel.: +353 17084756.

E-mail address: marian.crowleyhenry@nuim.ie (M. Crowley-Henry).
}

what is currently known about STIAs in the context of international mobility from the IHRM lens. Then we introduce the deployment cycle, a framework which is used in the specific context of military STIAs. Next, we provide information on the context and content of the exploratory research, where a limited number of qualitative interviews were conducted with short-term international assignees in the Irish Defence Forces. Finally, we consider the implications of our research for IHRM. The research contributes to IHRM as follows. Firstly, our paper focuses exclusively on STIAs where a dearth of research currently exists. Starr (2009) and Starr and Currie (2009) have explored the expectations of short-term international assignees in multinational corporations (MNCs) on repatriation. Tahvanainen, Welch, and Worm (2005) explored STIAs in eleven Finnish MNCs. However, our paper examines employees beyond the domain of the MNC, which is our second contribution. Thirdly, we suggest the implications of our study for IHRM.

\section{Short-term international assignments and the assignment cycle}

Interest in short-term international assignments within IHRM Field

This paper is concerned with short-term international assignments (STIAs), which is when the employees of an organization are assigned internationally for a temporary period of time not extending one year (Vance \& Paik, 2011). Short-term international assignments have been under-explored in IHRM theory and research to date. Rather, the focus in international human resource management has been on expatriates that are assigned overseas 
by their employing organization (usually a multinational corporation/MNC) for periods of more than one year (e.g., Brewster \& Scullion, 1997; Doherty, Dickmann, \& Mills, 2011; Dowling, Festing, Engle, 2008; Stahl \& Björkman, 2006; Yan, Zhu, \& Hall, 2002).

More recently this focus has been increasingly supplemented by a growing interest in self-initiated expatriates (Al Ariss \& CrowleyHenry, 2013; Crowley-Henry, 2012; Doherty, Thorn, \& Richardson, 2013; Doherty et al., 2011; Howe-Walsh \& Schyns, 2010), skilled migrants (Al Ariss, 2010; Al Ariss, Koall, Özbilgin, \& Suutari, 2012) and transnationals (Banai \& Harry, 2004; Beaverstock, 2005), where the international mobility is sustained over a long, potentially permanent duration.

However, other forms of international mobility remain on the periphery of empirical research. Frequent business travellers or flexpatriates (Demel \& Mayrhofer, 2010; Mayerhofer, Hartmann, \& Herbert, 2004a; Mayerhofer, Hartmann, Michelitsch-Riedl, \& Kollinger, 2004b) and those on short-term assignments (Starr, 2009; Starr \& Currie, 2009; Tahvanainen et al., 2005) are two categories of international assignments which have received less academic attention to date. This is surprising given that some researchers (Tahvanainen et al., 2005) position short-term assignments as the most popular form of non-standard international assignments in practice. Additionally it is suggested that short-term international assignments are an increasingly used international staffing alternative for organizations due to the increased pressures on organizations to be cost efficient and the lack of host country talent (Vance \& Paik, 2011, p. 138).

\section{Current knowledge on short-term international assignments (STIAs)}

Both STIAs and expatriate assignments have in common that the international mobility is an initiative which is required by the employing organization. This characteristic distinguishes shortterm and organization-assigned expatriate assignments from other international mobility forms such as self-initiated expatriation, migration and transnational mobility. Both also differ from flexpatriation (frequent business trips) in that the duration spent in the host country environment is more than one month at any given time.

STIAs are defined as being less than a year in duration (Vance \& Paik, 2011), with expatriate assignments generally between a year and five years in length (Collings et al., 2007; Doherty et al., 2011). Harris, Brewster, and Sparrow (2003) qualify STIAs as being between three months and one year in duration, while Collings et al. (2007, p. 205) define 'a short-term international assignment as a temporary internal transfer to a foreign subsidiary of between one and twelve months duration'. For the purpose of this paper, we refer to short-term international assignments as temporary foreign assignments of less than one year duration, in keeping with Vance and Paik (2011).

Variations to the term 'short-term international assignment' exist, even though they all refer to the same situation of a temporary short-term (less than one year) international assignment. These terms include 'short-term foreign postings' and 'extended business traveller' (Briscoe \& Schuler, 2004, p. 216), 'secondments', 'shortterm assignments abroad', 'short-term foreign assignments', or 'short-term foreign work assignments' (Vance \& Paik 2011, p. 138). In this paper we refer to the phenomenon as short-term assignments and to those that embark on such assignments as short-term assignees.

Despite terminology variations, it is clear from the literature that STIAs are required by the employing organizations, are temporary in nature, and do not exceed one year. Tahvanainen et al. (2005, p. 670) found that STIAs are used in the same way as expatriate assignments: 'for position filling, skill transfer or management control', as well as 'to simultaneously facilitate management development' (2005, p. 670). Short-term assignments are considered beneficial for the employee in that the 'foreign assignments can provide an interesting break, challenge, and professional development opportunity for employees who have worked in the same domestic location for a long period of time' (Vance \& Paik, 2011, p. 138). However, one of the challenges of assignments (short-term and longer-term) is if the assignee will have a job in the home country on return from the assignment (Tahvanianen et al., 2005), what that position may be, and if it takes the international learning into consideration. A further disadvantage is reflected in personal health issues (including alcoholism and stress) and strain on family relationships due to separation (Tahvanainen et al., 2005).

With regards to the advantages of STIAs to the organization, it is the consensus that STIAs are more cost efficient for organizations since they do not include the relocation of the assignee's family (Briscoe \& Schuler, 2004; Vance \& Paik, 2011). This is in comparison with those expatriates on long term assignments that move with their families for the duration of the assignment (Collings et al., 2007). While organizational support is expected for the families of organization-assigned expatriates that are accompanied internationally, for short-term assignees' families that do not relocate, the need for such organizational support is not explored. Festing and Perkins (2008, pp. 154-155) categorize short-term assignees as generally less expensive for the organization and less well compensated. They qualify this in differentiating between assignments of less than six months and those assigned for between six months and one year who generally receive rewards in line with the long-term expatriate assignments. Overall the cost efficiency and lack of complexity associated with short-term international assignments when compared to long term expatriate assignments is accepted in the conceptualization of STIAs in IHRM literature.

\section{The assignment cycle and the deployment cycle}

In international human resource management literature, the organization-assigned expatriation cycle (Harzing \& Christensen, 2004; Sparrow, Brewster, \& Harris, 2004) consists of three stages: pre-departure, assignment and post-assignment phase (Borg \& Harzing, 1995). For each of these stages the organization is encouraged to offer training and support to prepare the expatriate for the international assignment, to mentor them during the assignment, and to provide career opportunities after the assignment (Linehan \& Scullion, 2001).

Military organisations, similar to commercial organisations, require personnel to serve overseas as a routine part of their service. The military are well versed in deploying personal overseas (Defence Forces HRM Report, 2011). Examining literature on the deployment of military forces, the Pincus, House, Christenson, and Adler (2007) deployment framework considers a comprehensive five stage process. They identify the period of deployment as being a minimum of six months, which dovetails well with the situation pertaining to the Irish Defence Forces, where deployments are generally of four to six months, and can in some cases extend to 12 months. They divide the experience into five distinct stages, namely pre-deployment, deployment, sustainment, re-deployment and post-deployment.

The pre-deployment stage begins when the soldier is warned of his tour of duty, and ends on deployment. This involves preparation administration requirements/training and advance warning for the family. This stage can be elastic and can be almost nonexistent or can last for up to a year. It is characterised by feelings of loss and denial, with the deploying family member spending time away in preparatory training. There can be emotional conflict as the soldier begins the bonding and relationship forming 
necessary within a new unit preparing for period can be characterised by significant friction within the family setting.

The deployment stage is the first month that the soldier is away on the international placement. Training and counselling for military personnel takes place during this stage. It is characterised by mixed emotions from the various family members, ranging from relief that the absence has finally started, to disorientation and loneliness. There can be sleep difficulties and some security issues.

Sustainment begins from completion of the first month until the penultimate month of the deployment period. Extra financial income is paid, routines are established and support is available with colleagues. It is characterized by the development of new routines for both the deployed person and the family. Those at home can experience greater confidence, feelings of increased independence and control.

The re-deployment stage begins one month before the soldier returns home, and can involve conflicting emotions. The anticipation and excitement of the homecoming can be tempered with apprehension of high expectations on both sides for the deployed personnel and the remaining families.

Post-deployment begins on arrival home. The duration of this stage can also vary, depending on the adaptability of the individual family. The euphoria of the initial meeting can be followed by a 'honeymoon period'. There can be tension associated with redefinition of roles and boundaries, characterised by feelings of loss of independence and some resentment.

The Pincus et al. (2007) deployment cycle is particularly sensitive to the different stages in military deployment. Given the context and organizational specificity of our study, as well as the dearth of conceptual development concerning STIAs currently in the IHRM domain, an awareness of the deployment cycle from the military perspective could be of benefit to the conceptual development of STIAs within IHRM.

\section{Motivations to undertake international assignments}

The organization's rationale for using short-term international assignments was outlined earlier in the paper, as well as the limited literature on the benefits and challenges of STIAs for the individual assignees. However in IHRM literature on the longer-term organization-assigned expatriate, there have been a number of publications on the motivations to embark on an international assignment (e.g., Dickmann, Doherty, Mills, \& Brewster, 2008; Doherty et al., 2011; Dowling et al., 2008; Richardson \& McKenna, 2002).

International assignments offer adventure to the assignee. Expatriates can move to a new country, experience a new culture, and grow personally in adjusting to the new environment (Richardson \& McKenna, 2002). Organization-assigned expatriation assignments are lucrative for the expatriates, in that a number financial incentives and benefits may be offered by the organization in order to entice the expatriate to move (Dowling et al., 2008). Expatriation assignments provide individuals with the opportunity to extend their role and responsibilities in the organization. This personal career development pathway motivates individuals to move internationally in order to increase their organizational knowledge and promotional opportunities in the organization (Dickmann et al., 2008; Doherty et al., 2011). Indeed Linehan and Scullion (2001) suggest career advancement is the primary reason why individuals partake in international assignments.

\section{Family support from the organization}

Much of the literature from the military domain concerning member deployments indicates that pre-existing conditions within families will have a significant bearing on how well they cope with deployments (e.g., Van Breda, 1999). The importance of including family (spouse and children) in the preparation and support process when it comes to longer term expatriate assignments is emphasised in IHRM (Black \& Stephen, 1989; Cole, 2011; Fish \& Wood, 1997; Qin \& Baruch, 2010), with expatriation failure predominately ascribed to failure in the expatriate's family/spouse to adapt to the new country (Bauer \& Taylor, 2001; Black \& Gregersen, 1991; De Cieri, Dowling, \& Taylor, 1991; Tung, 1987). However, for short-term assignments, family and spouse do not relocate internationally with the assignee. Therefore the assumption has been that spousal and family issues are mitigated when using short-term assignees.

While the deployment model we described in the previous section acknowledges the impact on the military personnel and his/ her family interaction over the deployment cycle, this can be aligned with the longer term expatriation cycle in international HRM literature, where organizational support for families also moving internationally is recommended. However, the relevance and requirement of organizational support for non-relocating families of members on short-term international assignments has been under-explored in IHRM.

\section{Context, research approach and sample}

In particular organizations and for particular staff, the requirement for short-term assignments is paramount. The Irish Defence Forces, as directed by the Irish Government, aims 'to contribute to the maintenance of international peace and security through participation in approved United Nations - Mandated peace support, crisis management and humanitarian relief operations' (Defence Forces Annual Report, 2011). The national commitment to this aim is borne out by the numbers of military personnel assigned to service overseas in recent times. For example, in 2010, 1639 or $19 \%$ of all Enlisted Personnel served overseas. In the case of officers, the number was 340 , or $32 \%$ of all officers (Defence Forces Annual Report, 2011). The White Paper on Defence: Review of Implementation (2007, p. 21) stated that 'In any given calendar year up to 2000 personnel are either overseas, preparing to deploy or returning from a tour of duty'. Considering the size of the Defence Forces of 10,500 personnel in total, these figures portray an organization in which deployment overseas for extended periods is a routine, regular and highly significant part of operations.

Short-term international assignments are necessary requirements for promotion at all levels in the Irish Defence Forces, that is, at every rank an Officer $^{1} /$ Non-Commissioned Officer $^{2}$ (NCO)/private serves, he/she is required to go overseas in that rank in order to be considered for promotion to the next higher rank. Overseas service, therefore, is an integral part of a military career path (Defence Forces Annual Report, 2011), with military personnel required to participate in overseas missions throughout their career as part of continuous professional development. Through overseas service, command and leadership appointments at different levels ranging from junior appointment holders such as Lieutenant to senior appointment holders such as Colonel are examined throughout a military officer's career path. Significantly, a higher weighting is assigned to the performance report from overseas service than to service at home (Defence Forces HRM Report, 2011).

These overseas peace-keeping assignments typically last up to six months (but can be extended for periods of up to one year), during which time military personnel are away from their family, home and familiar surroundings. Military personnel are unaccom-

\footnotetext{
1 Officers: Commissioned Officers from the rank of 2/Lt to Chief of Staff (CEO) the management branch of a military force.

2 NCO: Non Commissioned Officer, typically from the rank of Corporal to Battalion Sergeant Major, military personnel not awarded a commission.
} 
panied on these missions due to the nature of the mission environment, particularly the hostile environment and nature of military formations. These personnel fit the criteria of being on short-term international assignments, since they move internationally via their employing organization for a temporary period of time of less than one year.

In order to explore STIAs in a military context and glean data on STIAs in practice in the military, in-depth qualitative interviews were conducted with a small sample of personnel and their remaining spouse from the Irish Defence Forces. In total, ten people were interviewed (6 serving personnel and 4 spouses/partners). The inclusion criteria were that participants were members or spouses of members of the Irish Defence Forces, who had been deployed overseas. We used purposeful sampling in the selection of participants. The second author to this paper is a retired Military officer which facilitated access to the population under examination. Six military personnel and their partners were interviewed for the purposes of this study. In one of the cases, both partners were members of the Irish Defence Forces and so eligible to be sent on international deployment. The limitation of the very small sample size renders that the findings cannot be generalized. However, this was an exploratory study, the aim of which was to explore STIAs in a military context and to consider the implications for IHRM. The identification and selection process secured participants who had 'lived experience' in the particular area of the study, who were happy to talk about their experiences, and who were diverse enough from one another to provide for rich and unique stories of the particular experience (Van Manen, 1997). Despite the restrictive sample size and number of interviews, we gathered a mix of personnel who had experienced STIAs, with a blend of age, rank, gender and family types. All were willing to take part, and were selected and approached outside the military system, which set a tone of informality and confidentiality.

The military personnel included two private soldiers, a sergeant, two junior officers and one senior officer. Length of military service ranged from five to thirty-seven years. Within the families, two of the military members were women, and four were men. The number of dependent children within families varied from one to four. Each family brought a personal dimension to the research that enriched the text and allowed for meaningful analysis. Some of the participants had experienced traumatic incidents while on overseas service. This offered a perspective on how the experience may have altered the phenomenon of overseas deployment and its impact on them and on their family members. Other families had specific domestic factors, including dependent children with special needs. One family encountered overseas deployment having suffered the recent loss of a child.

Four other couples were approached but declined to participate in the study. Their general concern was a desire to maintain family privacy in an institution as small as the Irish Defence Forces. This limitation suggests a challenge in undertaking research in organizations such as the Military or the Defence Forces, due to the size of the organization and the concern that partaking in such research could prove detrimental to career progression in the future. However, the six military personnel (and their respective spouses) that engaged in this study did so comprehensively and provided a rich set of findings.

Detailed interviews with the couples were transcribed and their narratives concerning the STIA experience at the individual level were analysed using content analysis. The interview guide was constructed from literature on the deployment cycle, discussed previously, whereby the interviewees were asked to relate their lived experiences through the different stages. All names mentioned during the course of the interviews have been changed to protect the identity of the research participants and their families.
Quotations from participants used are attributed in the following manner: The family number is indicated as 'FAM 01', while the subsequent $\mathrm{S}$ or $\mathrm{P}$ indicates whether the quotation is from the partner of the soldier, or the soldier themselves. Where both are members of the Defence Forces, the $\mathrm{S}$ is attributed to the person whose overseas service has been agreed to have had most impact on the life of the family.

Data were analyzed in a two-stage process that was heavily inductive (Lofland \& Lofland, 1995). During the first stage, transcribed interviews were examined for instances during which issues pertaining to the overseas deployment were noted. The second stage of coding was an analysis of the initial codes. During this focused coding (Lofland \& Lofland, 1995), the initial codes were sorted into similar groups, to which labels were then attached. Subsequently the analysis and synthesis of results was carried out through feedback and discussion with the participants. The next section considers the findings from our exploratory study in the context of what is currently known and taken for granted in IHRM concerning STIAs.

\section{Findings, discussion and implications for IHRM}

\section{Overview}

Table 1 summarizes the current conceptualization of short-term international assignments in IHRM as presented in the literature review of this paper. This section focuses on columns $C$ and $D$, where the current conceptualization of short-term international assignments is discussed, supplemented with quotes from our empirical study, where relevant.

\section{Dearth of empirical research}

The organizational operations of the Irish Defence Forces are fundamentally different to commercial organizations. However, it is an organization which routinely sends its members on shortterm international assignments and from which a development of how short-term international assignments are conceptualized can be initiated. Parallels could be drawn between the Irish military and the military in other countries; or positions which require training to be put into action on site, in a specific context (such as oil exploration, mining and drilling). Research in organizations where short-term international assignments are a standard component of a career with that organization would strengthen the conceptualization of short-term international assignments as a category of international assignments within IHRM in their own right.

Equally, the specificity of the context we have explored (Irish Defence Forces sent on peacekeeping missions overseas) cannot be ignored, but rather presents a more complex picture of shortterm international assignments as they are lived through in practice. The sending organization and the receiving environment play a major role in the degree of challenge and stress an assignment entails for the individual assignee and for his/her significant others. Our study confirms that the context in which organizations send their employees overseas is not homogeneous and should not be accepted as such, but rather it is more complex and multi-layered. The assumption, therefore, that short-term assignments are less complex is not straight-forward, specifically for the sample addressed in this paper, and needs to be unpacked for specific cases in order to fully grasp the implications of short-term assignments. This underlines the need to unpack short-term assignments relative to organization and context. 
Table 1

Current conceptualization of short-term international assignments and future research agenda for IHRM.

\begin{tabular}{|c|c|c|}
\hline A - literature focus & B - literature source & C - Irish Defence Forces \\
\hline $\begin{array}{l}\text { Focus on the multinational } \\
\text { organization with research on } \\
\text { organization-assigned short- } \\
\text { and longer term expatriates }\end{array}$ & $\begin{array}{l}\text { Brewster and Scullion (1997), } \\
\text { Doherty et al. (2011), Dowling } \\
\text { et al. (2008), Stahl and Björkman } \\
\text { (2006), Yan et al. (2002) }\end{array}$ & $\begin{array}{l}\text { Specific organizational context } \\
\text { of the Defence Forces }\end{array}$ \\
\hline $\begin{array}{l}\text { Rationale for short-term } \\
\text { international assignments - } \\
\text { position filling }\end{array}$ & Tahvanainen et al. (2005) & $\begin{array}{l}\text { Sent to fill positions in peace- } \\
\text { keeping, PR peace-enforcement } \\
\text { duties }\end{array}$ \\
\hline $\begin{array}{l}\text { Rationale for short-term } \\
\text { international assignments - } \\
\text { skill transfer }\end{array}$ & Tahvanainen et al. (2005) & $\begin{array}{l}\text { The short-term assignments } \\
\text { provide the military with the } \\
\text { opportunity to transfer skills } \\
\text { they learned at home into } \\
\text { practice overseas during peace } \\
\text { keeping and/or peace } \\
\text { enforcement missions }\end{array}$ \\
\hline $\begin{array}{l}\text { Rationale for short-term } \\
\text { international assignments - } \\
\text { management control }\end{array}$ & Tahvanainen et al. (2005) & $\begin{array}{l}\text { Regular feedback to } \\
\text { commanding officers required } \\
\text { by deployed personnel }\end{array}$ \\
\hline
\end{tabular}

Rationale for short-term

international assignments

- Management development

- Professional development, challenge

Rationale for short-term international assignments provides a break from routine of domestic placement

Possible issue - job on return from the international shortterm assignment
Tahvanainen et al. (2005)Vance and Paik (2011)

Vance and Paik (2011)

Tahvanainen et al. (2005)
It is a requirement of the Irish Defence Forces that all personnel serve overseas at each promotional rank

Regular short-term international assignments expected over the course of all military personnel's careers in the Irish Defence Forces

Not an issue for the Irish Defence Forces as the short-term assignment is an integral part of their career development and is compulsory. There is a position for them on return from the assignment.

However, for some that return home from overseas, the pedestrian routine of their job in Ireland leads to boredom and has meant that some leave the organisation looking for a more challenging environment Military personnel on overseas duties are well compensated, earning a tax-free premium while overseas effective as they do not include family relocation

Stages in short-term international assignments not considered; rather the focus is on the organizationassigned expatriate process and its stages (pre-move, incountry, post-move)
Briscoe and Schuler (2004),

Festing and Perkins (2008),

Vance and Paik (2011)

Borg and Harzing (1995)
Authors specifically consider military deployment cycles (e.g. Pincus et al., 2007) recognising their specificity; incorporating short-term international assignments.
D - comments pertaining to literature as it aligns with empirical study

Requirement to include organizational context in discussions on short-term international assignments. Relevance of our study for other command and control type organizations (e.g., military) Supported by our study

Supported by our study Indeed the overseas assignments is the opportunity for military personnel to put into practice what they have learned in the home context

Supported by our study Management structures at all levels are tested in peace keeping and peace enforcement missions. Similarly the Irish military command structure feeds into an international force context in overseas missions. As well, the overseas unit feeds back into the Irish (those based in Dublin) command structure Supported by our studyIndeed this is one of the main reasons for short-term assignments

Supported by our study as in the context of the military deployment, military personnel get the opportunity to use overseas what they have learned in training in Ireland Not supported in our study. However the opposite is more likely: if the personnel fails to undertake short-term international assignments, how this impacts on their career progression; how career progression is informed by the short-term assignments undertaken

Not inexpensive - premia paid to deployed personnel assigned overseas.

The context of the assignment requires closer examination. Not a 'one size fits all' situation Requirement to focus on stages for short-term international assignees in this context as much as there has traditionally been a focus to consider the expatriation stages for longer term organization-assigned expatriates.

Suggest learning for IHRM from military deployment literature, particularly for short-term assignments to potentially remote or dangerous contexts (such as for organizations engaged in petrochemical, drilling/exploration contexts) 
Table 1 (continued)

\begin{tabular}{|c|c|c|c|}
\hline A - literature focus & B - literature source & C - Irish Defence Forces & $\begin{array}{l}\text { D - comments pertaining to } \\
\text { literature as it aligns with } \\
\text { empirical study }\end{array}$ \\
\hline $\begin{array}{l}\text { Motivations to embark on } \\
\text { international assignments }\end{array}$ & $\begin{array}{l}\text { Dickmann et al. (2008), Doherty } \\
\text { et al. (2011), Dowling et al. } \\
\text { (2008), Richardson and McKenna } \\
\text { (2002) }\end{array}$ & $\begin{array}{l}\text { Motivations to move for } \\
\text { adventure, financial and career } \\
\text { development reasons similar to } \\
\text { motivations for organization- } \\
\text { assigned expatriates }\end{array}$ & $\begin{array}{l}\text { However, there are temporal } \\
\text { changes in motivations to } \\
\text { embark on short-term } \\
\text { international assignment from } \\
\text { challenge, career, to rather not... } \\
\text { There is a requirement to map } \\
\text { motivations over time and not to } \\
\text { consider them as static or } \\
\text { uniform across all individuals. }\end{array}$ \\
\hline $\begin{array}{l}\text { Organizational support for } \\
\text { remaining family not a HR/ } \\
\text { organizational focus with } \\
\text { regards to short-term } \\
\text { international assignments }\end{array}$ & $\begin{array}{l}\text { Briscoe and Schuler (2004), } \\
\text { Collings et al. (2007), Vance and } \\
\text { Paik (2011)) }\end{array}$ & $\begin{array}{l}\text { Family are informed of } \\
\text { organizational support } \\
\text { initiatives, but the take up of } \\
\text { those initiatives are low in } \\
\text { practice due to perceived } \\
\text { implications of family 'not } \\
\text { coping' on the deployed military } \\
\text { personnel's career }\end{array}$ & $\begin{array}{l}\text { Not supported by our study. } \\
\text { Requirement to study the } \\
\text { context of the organization and } \\
\text { location of deployment. } \\
\text { More complicated than } \\
\text { previously purported. } \\
\text { Requirement for organizational } \\
\text { support for family but take up } \\
\text { low due to potential } \\
\text { ramifications for the personnel. } \\
\text { Research difficult due to } \\
\text { command/control context and } \\
\text { potential ramifications for } \\
\text { personnel. } \\
\text { Further research required on } \\
\text { organizational support for } \\
\text { remaining families of short-term } \\
\text { international assignees }\end{array}$ \\
\hline $\begin{array}{l}\text { Importance of including family } \\
\text { in decisions to send } \\
\text { employees on expatriate } \\
\text { assignments }\end{array}$ & $\begin{array}{l}\text { Black and Stephen (1989), Black } \\
\text { and Gregersen (1991) }\end{array}$ & $\begin{array}{l}\text { Family support programmes in } \\
\text { place but on a voluntary basis }\end{array}$ & $\begin{array}{l}\text { Family matters. Our research } \\
\text { shows that regular short-term } \\
\text { international assignments } \\
\text { impact on the family } \\
\text { relationship and dynamic, and } \\
\text { can have negative implications } \\
\text { for career progression } \\
\text { motivations over time }\end{array}$ \\
\hline $\begin{array}{l}\text { Not featured in the literature. } \\
\text { Research gap identified in our } \\
\text { study }\end{array}$ & & $\begin{array}{l}\text { Short-term international } \\
\text { assignments are a necessary and } \\
\text { integral component of the career } \\
\text { path for military personnel in } \\
\text { the Irish Defence Forces }\end{array}$ & $\begin{array}{l}\text { Short-term international } \\
\text { assignments as integral } \\
\text { component of job description. } \\
\text { Requirement to deepen } \\
\text { investigation of organizations } \\
\text { routinely engaged in short-term } \\
\text { international assignments in } \\
\text { order to inform theory } \\
\text { development }\end{array}$ \\
\hline
\end{tabular}

\section{Current knowledge on short-term assignments}

The literature cites a number of reasons for short-term assignments, which our exploratory study confirms (see Table 1). However, the literature neglects that, for certain organizations, short-term international assignments are an inherent part of their operations and vital to their ongoing performance. In the Irish Defence Forces, deployments are generally of four to six months, and can in some cases extend to 12 months. Further research on the importance and use of STIAs across organizations would develop the conceptualization of this international staffing category within IHRM.

Short-term assignments as a means of managerial control is confirmed in our study, where the military personnel are required to provide feedback updates to their commanding officers on a regular basis. With regards to short-term international assignments being less well compensated that longer term assignments, publications to date in this space speak to short-term assignments of multinational private-sector organizations rather than to the specific group with which this paper is concerned: military personnel. In the military context, deployed personnel on STIAs are very well compensated (and earn a tax-free premium).

In keeping with IHRM literature espousing the STIA experience for the individuals (Vance \& Paik, 2011), our exploratory study con- firmed that the experience was overwhelmingly positive from a professional point of view. It offers a change from routine regimental life and is usually an interesting and rewarding appointment, The management development dimension of undertaking an international assignment (Tahvanainen et al., 2005) is also confirmed: "Great job satisfaction....lots more flexibility and authority than at home" (FAM 03S).

Individual concern regarding the position they will occupy in the organization on return from their short-term assignment is not an issue in the military context. The assignee's position in the military is determined by higher command, and he/she must be willing to move to that determined position as part of his/her military career. There is a definite position in the organization for all military personnel, therefore alleviating any concerns that jobs in the home country may not be available in the organization on return from an assignment.

\section{Deployment cycle}

We presented the military deployment cycle earlier in the paper. It consists of five very distinct stages which are specific to the military situation. We suggest that it can inform IHRM theory on short-term international assignments in that it draws attention to the relevance of organizational support for the assignee over 
different stages in the assignment; that all assignments and individuals are different and so different support requirements may be needed, rather than a one-size fits all approach across organizations. We suggest that in order to develop what is known about STIAs in IHRM, that learning from other fields, such as the deployment cycle from military literature, is possible.

\section{Motivations to undertake international assignments}

As our study has shown, it is a requirement of the Irish Defence Forces that all personnel serve overseas on short-term international assignments at each promotional rank. In Ireland, the military are always training, whereas when they deploy to either a peace keeping and/or a peace enforcement mission, they transfer their knowledge and expertise to active conflict situations; in other words, they put their training into practice.

Our study confirms that there are different individual motivations with regards to short-term international assignments, within the context of appreciating that short-term international assignments are not optional, but a core part of membership in the Irish Defence Forces. However, the temporal dimension of changing motivations over time is not explored in IHRM. Our study, however, highlights that the motivations evolve over time. In FAM 03 for instance, the initial incentive was relatively carefree: "The early deployments were a sense of adventure - to see what it was like. . and I knew it was part of the job. . .of course financially there was an incentive as well" (FAM 03S), while the financial incentive was also underlined: "Money, that's the main one, that's the main motivation now" (FAM 02P). However, over time and having experienced different short-term international assignments, motivations change and often become more a family than individual concern, as the following quote describes: "I put the Army first in the early days, but I have had an epiphany... at the end of thirty-one years they will give me my green book and say thanks for the memories...so for me it's family first and job second. . .my family's happiness is my first concern" (FAM 01S).

The temporal nature of evolving motivations to undertake STIAs is therefore relevant, but has not been explored in IHRM. In the case of the Irish Defence Forces, personnel are mandated to serve overseas over the course of their careers. A primary motivation for further service overseas is career based. There is acceptance within some of the families that promotion is predicated on a satisfactory overseas record, and that as such, it cannot be avoided: "If you don't serve overseas in your rank, you will not get promoted....this is something I have to consider" (FAM 01S), similarly another respondent noted:"There is no real motivation at the moment, it's just something that has to be done, and the only way out of it is to leave the organization" (FAM 03S). The implications of changing motivations to undertake STIA over time is important for IHRM theory and practice advancement, in that it suggests a closer contextual and individual analysis of STIAs is required.

\section{Family matters and requirement for organizational support}

The specificity of the organization (in our case, the Irish Defence Forces) and the context is vital when considering the organizational support requirements for individual members and their families. In such contexts, the involvement of the remaining family in, for instance, training on what the deployed individual will be doing and where he/she is going, could be supportive and alleviate some of the family stress associated with separation: "I have been on missions that have been highly stressful. ... and it feeds back and adds a whole new dimension of stress to the family" (FAM 03S).

In our small study, the perceived lack of organizational support and understanding directed toward the family situation was ex- pressed. There was a significant degree of frustration observed in relation to notification times, the processing of mandatory selection and overall family friendly career planning: "When Joe was born and only a few months old, I was detailed for Lebanon....and there was no choice in the matter. ...no consideration of the impact that might have on a family situation" (FAM 03S) another respondent noted: "I found it very hard. ...I rang in sick the morning I found out I was pregnant. . the response was unsympathetic. . I don't think I had a personal interview about it with anybody" (FAM 02S) and similarly: "On the Monday I brought Maggie to the hospital[to deliver our baby] I got a phone call to report for a medical ... that I was going to Lebanon" (FAM 04S).

The stress that the individual assignees and their remaining families encounter with regards to the STIAs is emphasized in our study. The perceived lack of importance weighted on the individual's prevailing family situation by the organization was negatively interpreted by the respondents and suggests the need for closer family involvement in all five stages of the deployment cycle (Pincus et al., 2007).

Organizational support for the remaining families surfaced frequently as a requirement, but with the complication that families did not want to jeopardise the military personnel's career by proactively seeking support from the military: “I wouldn't feel comfortable with using the service for anything other than an absolute emergency...I wouldn't feel secure...it's a question of privacy...not for me but for him...I would hate to think I had done something to damage his reputation" (FAM 01P).

Contrary to the IHRM literature which suggests there is no need for organizational support for families of short-term international assignees, our study positions the need to involve the remaining family in the details of the assignment (before, during, after) as essential:"The Organization cares about the employee 100\% - but it's not a normal job... The job involves your family because it impacts so much on your family... The full package is the soldier and the family, and this is not appreciated" (FAM 03S).

With regards to the implications for IHRM on the conceptual development of STIAs, our study suggests that organizational support for non-relocating family members may indeed be a requirement.

\section{Limitations of the study}

This paper has considered what is known in international management regarding short-term international assignments and has adopted a dialectical approach in considering that literature and literature on international assignments in general in parallel with the lived experiences of some deployed military personnel from the Irish Defence Forces. A major limitation of the paper is the restricted size of the sample that shared their experiences with us. Due to the specificity of the organization in question, the Irish Defence Forces, and the potential of being recognized in the study, further interviews were not possible. However, our focus was to consider a more holistic picture of short-term assignments from the point of view of the assignee and his/her remaining partner in the context of what is known about short-term international assignments in the management literature. Drawing on international human resource management literature, our focus was on advancing what is known in this space.

\section{Conclusions and recommendations for further research}

The paper has contributed to literature in the international human resource management field by focusing on an under-examined category of international staffing alternatives, namely the 
short-term international assignee. It has brought focus to shortterm international assignments as they are currently depicted in international human resource management. In addition, the study presented in this paper has concerned military personnel from the Irish Defence Forces, which differs from studies on employees from multinational corporations.

Three significant gaps were identified: the lack of research on short-term international assignments; the lack of research on international assignments beyond MNCs; the lack of questioning of the current conceptualization of short-term international assignments. We reviewed existing literature on short-term international assignments, international mobility and expatriate assignments in the IHRM domain. We then considered the existing IHRM literature in the context of an exploratory study we conducted within the Irish Defence Forces. In so doing, we addressed the first two gaps (a research focus on short-term international assignments in IHRM, research on organizations beyond the MNC in the IHRM field). We suggest that what is known about military deployments through the deployment cycle (Pincus et al., 2007) could be useful in developing the conceptualization of short-term international assignments in IHRM.

With regards to the third gap, our analysis confirms some aspects pertaining to short-term international assignments as portrayed in the existing literature, but questions others. Table 1 summarizes these. Our study confirms that STIAs warrant further attention in international human resource management than hitherto given. There are organizations and professions where regular STIAs are an integral component of career advancement and organizational life; these warrant deeper analysis of short-term international assignments.

The consideration to date that short-term international assignments are less costly and less complicated than traditional organization-assigned expatriation assignments is questioned. Despite discussions to the contrary in the literature, our research stresses the need for organizational support for the remaining family over the course of the assignment in order to alleviate or mitigate concerns regarding the international assignee, the context of the deployment and the separation. The need for organizational support for remaining families corroborates findings for MNC expatriates in IHRM literature.

Furthermore, our research highlights that the temporal nature of evolving motivations to undertake short-term international placements, which has not been explored in the literature and requires further research. The ramifications for IHRM of changing motivations to embark on international assignments over time on turnover, retention and productivity need to be addressed in future studies. Monetary rewards balanced by an understanding of the individual's need to balance his/her family commitments while overseas, and how priorities and motivations change over time need to be addressed.

Finally, we conclude that what is currently known about STIAs cannot be generalized across organizations, but requires organizational and contextual focus.

\section{References}

Al Ariss, A. (2010). Modes of engagement: Migration, self-initiated expatriation, and career development. Career Development International, 15(4), 338-358.

Al Ariss, A., Koall, I., Özbilgin, M., \& Suutari, V. (2012). Careers of skilled migrants: Towards a theoretical and methodological expansion. The Journal of Management Development, 31(2), 92-101.

Al Ariss, A., \& Crowley-Henry, M. (2013). Self-initiated expatriation and migration in the management literature: Present theorizations and future research directions. Career Development International, 18(1), 78-96.

Banai, M., \& Harry, W. (2004). Boundaryless global Careers: The international itinerants. International Studies of Management \& Organization, 34(3), 96-120.

Bauer, T. N., \& Taylor, S. (2001). When managing expatriate adjustment, don’t forget the spouse. The Academy of Management Perspectives, 15(4), 135-137.
Beaverstock, J. V. (2005). Transnational elites in the city: British highly-skilled intercompany transferees in New York City's financial district. Journal of Ethnic and Migration Studies, 31(2), 245-268.

Black, J. S., \& Gregersen, H. B. (1991). The other half of the picture - Antecedents of spouse cross-cultural adjustment. Journal of International Business Studies, 22(3), $461-477$.

Black, J. S., \& Stephen, G. K. (1989). The influence of the spouse on American expatriate adjustment and intent to stay in Pacific Rim overseas assignments. Journal of Management, 15(December), 529-544.

Borg, M., \& Harzing, A. W. (1995). Composing an international staff. In A. W. Harzing \& J. Van Ruysseveldt (Eds.), International human resource management. London: Sage.

Brewster, C., \& Scullion, H. (1997). A review and agenda for expatriate HRM. Human Resource Management Journal, 7(3), 32-41.

Briscoe, D. R., \& Schuler, R. S. (2004). International human resource management (2nd ed.). London and New York: Routledge.

Cole, N. D. (2011). Managing global talent: Solving the spousal adjustment problem. International Journal of Human Resource Management, 22(7), 1504-1530.

Collings, D. G., Scullion, H., \& Morley, M. J. (2007). Changing patterns of global staffing in the multinational enterprise: Challenges to the conventional expatriate assignment and emerging alternatives. Journal of World Business, 42(2), 198-213.

Crowley-Henry, M. (2012). Re-conceptualizing the career development of self initiated expatriates: Rivers not ladders. The Journal of Management Development, 31(2), 130-141.

De Cieri, H., Dowling, P. J., \& Taylor, K. F. (1991). The psychological impact of expatriate relocation on partners. International Journal of Human Resource Management, 2(3), 377-414.

Defence Forces Annual Report (2011). The Annual Report of the Defence Forces 2011. Published by the Department of Defence (Ireland)

Defence Forces HRM Report (2011). Human Resource Management in the Irish Defence Forces 2011. Published by the Department of Defence (Ireland).

Dickmann, M., \& Baruch, Y. (2011). Global careers. New York and Oxon/London UK: Routledge.

Dickmann, M., Doherty, N., Mills \& Brewster, C. (2008). “Why do they go? Individual and corporate perspectives on the factors influencing the decision to accept an international assignment. International Journal of Human Resource Management, 19(4), 731-751.

Demel, B., \& Mayrhofer, W. (2010). Frequent business travelers across Europe: Career aspirations and implications. Thunderbird International Business Review, 52(4), 301

Doherty, N., \& Dickmann, M. (2008). Capitalizing on an international career. Career capital perspectives. In M. Dickmann, C. Brewster, \& P. Sparrow (Eds.), International human resource management. A European perspective 2nd ed., (pp. 240-262). London and New York: Routledge, chapter 12.

Doherty, N., Dickmann, M., \& Mills, T. (2011). Exploring the motives of companybacked and self-initiated expatriates. The International Journal of Human Resource Management, 22(3), 595-611.

Doherty, N., Thorn, K., \& Richardson, J. (2013). Self-initiated expatriation: Career experiences, processes and outcomes, Special Issue. Career Development International, 18(1).

Dowling, P. J., Festing, M., \& Engle, A. D. Sr., (2008). International human resource management. London: Thomson.

Festing, M., \& Perkins, S.J. (2008). Rewards for internationally mobile employees. In M. Dickmann, C. Brewster, \& P. Sparrow (Eds.), International Human Resource Management. A European Perspective. 2nd ed., (pp. 150-173). London and New York: Routledge, chapter 8.

Fish, A., \& Wood, J. (1997). Managing spouse/partner preparation and adjustment. Developing a meaningful portable life. Personnel Review, 26(6), 445-466.

Harris, H., Brewster, C., \& Sparrow, P. (2003). International human resource management. London: CIPD.

Harzing, A.-W., \& Christensen, C. (2004). Expatriate failure: time to abandon the concept? Career Development International, 9(7), 616-626.

Hayton, J. C., Biron, M., Christiansen, L. C., \& Kuvaas, B. (2012). Global human resource management casebook. New York and Oxon/London: Routledge.

Howe-Walsh, L., \& Schyns, B. (2010). Self-initiated expatriation: Implications for HRM. International Journal of Human Resource Management, 21(2), 260-273.

Linehan, M., \& Scullion, H. (2001). Selection, training, and development for female international executives. Career Development International, 6(6), 318-323.

Lofland, J., \& Lofland, L. (1995). Analyzing social settings. Belmont, CA: Wadsworth.

Mayerhofer, H., Hartmann, L. C., \& Herbert, A. (2004a). Career management issues for flexpatriate international staff. Thunderbird International Business Review, 46(6), 647-666.

Mayerhofer, H., Hartmann, L. C., Michelitsch-Riedl, G., \& Kollinger, I. (2004b). Flexpatriate assignments: A neglected issue in global staffing. International Journal of Human Resource Management, 15(8), 1371-1389.

Pincus, S. H., House, R., Christenson, J., Adler, L.E., (2007). The emotional cycle of deployment: A military family perspective. <http://www.hooah4health.com/ deployment/familymatters/emotionalcycle.htm> Accessed 01.11.09.

Qin, C., \& Baruch, Y. (2010). The impact of cross-cultural training for expatriates in a Chinese firm. Career Development International, 15(3), 296-318.

Richardson, J., \& McKenna, S. (2002). Leaving and experiencing: Why academics expatriate and how they experience expatriation. Career Development International, 7(2), 67-78.

Sparrow, P., Brewster, C., \& Harris, H. (2004). Globalizing human resource management. London: Routledge. 
Stahl, G. K., \& Björkman, I. (Eds.). (2006). Handbook of research in international human resource management. Cheltenham, UK: Edward Elgar.

Starr, T. L. (2009). Repatriation and short-term assignments: An exploration into expectations, change and dilemmas. International Journal of Human Resource Management, 20(2), 286-300.

Starr, T. L., \& Currie, G. (2009). 'Out of sight but still in the picture': Short-term international assignments and the influential role of family. International Journal of Human Resource Management, 20(6), 1421-1438.

Tahvanainen, M., Welch, D., \& Worm, V. (2005). Implications of short-term international assignments. European Management Journal, 23(6), 663-673.

Tung, R. L. (1987). Expatriate assignments: Enhancing success and minimizing failure. The Academy of Management Executive, 1(2), 117-125.
Van Breda, A. D. (1999). Developing resilience to routine separations: An occupational social work intervention. Families in society: The Journal of Contemporary Human Services, 80(6), 597-605.

Van Manen, M. (1997). Researching lived experience: Human science for an action sensitive pedagogy. Albany, New York: University of New York Press.

Vance, C. M., \& Paik, Y. (2011). Managing a global workforce. Challenges and opportunities in international human resource management (2nd ed.). New York USA: M.E. Sharpe.

Yan, A., Zhu, G., \& Hall, D. T. (2002). International assignments for career building: A model of agency relationships and psychological contracts. Academy of Management Review, 27(3), 373-391. 